\title{
PEMBERIAN AMELIORAN DAN ISOLAT BAKTERI FIKSASI NITROGEN NON SIMBIOTIK (FNNS) UNTUK MENINGKATKAN PERTUMBUHAN DAN SERAPAN N TANAMAN PADI GOGO (Oryza sativa L.) PADA MEDIUM ULTISOL
}

\author{
Yoggie Prathama $^{1}$, Nelvia Nelvia ${ }^{1}$, Al Ikhsan Amri ${ }^{1}$ \\ ${ }^{1}$ Jurusan Agroteknologi Fakultas Pertanian Universitas Riau \\ Kampus Bina Widya Universitas Riau, Jl. HR. Soebrantas KM 12,5 Pekanbaru, Indonesia 28293 \\ Email : nelvia@unri.ac.id; Mobile :+6281371248740
}

\begin{abstract}
The need of rice as the staple food of the people of Indonesia has a deficit every year. Upland rice cultivation in dry land such as Ultisols became one of the alternatives to meeting the needs of rice. However, productivity of crop in Ultisols is low because of some problems of acidity and nutrients deficiency. It is necessary input such as ameliorants like biochar cocopeat of oil palm empty bunch compost (OPEBC) and the use of bacterial non-symbiotic nitrogen fixation (NSNF) to fix the problems. The research aims to study the effect of application of ameliorant and suspensions of bacterial isolates of NSNF on growth and N uptake by upland rice in Ultisols medium. The research was conducted at the Green House of the Faculty of Agriculture, University of Riau, Pekanbaru from Mei to September 2017. The research in form factorial experiment was arranged a completely randomized design (CRD). The first factor were ameliorant, consists of six type (biochar, cocopeat, OPEBC, biochar+cocopeat, biochar+OPEBC, each doses $50 \mathrm{~g} \mathrm{polybag}^{-1}$ and without ameliorant as a control). The second factor were suspensions of bacterial isolates of NSNF, consists of three levels (10 and $20 \mathrm{ml} \mathrm{polybag}^{-1}$ and without bacterial isolates as a control). The parameters observed were plant height, number of tillers, weight of dry shoot and roots, $\mathrm{N}$ uptake by shoot and roots. The results show that the application of ameliorant (biochar, cocopeat, OPEBC, biochar + cocopeat, biochar + OPEBC), each doses of $50 \mathrm{~g} \mathrm{polybag}^{-1}$ and suspensions of bacterial isolates of NSNF doses of 0,10 and $20 \mathrm{ml}$ polybag ${ }^{-1}$ increased plant height, number of tillers, weight of dry shoot and $\mathrm{N}$ uptake by shoot compared to control and the application of without ameliorant with suspension of bacterial isolates of NSNF doses of 0,10 and $20 \mathrm{ml} \mathrm{polybag}^{-1}$.
\end{abstract}

Key words : biochar, cocopeat, palm oil empty bunch, upland rice, ultisol

(c) 2018 Yoggie Prathama, Nelvia Nelvia, Al Ikhsan Amri

\section{PENDAHULUAN}

Beras sebagai makanan pokok sebagian besar penduduk Indonesia yaitu sumber energi utama bagi tubuh. Beras mengandung 77\% karbohidrat, 7,5\% protein, 9\% lemak dan mampu mencakupi $63 \%$ dari total kecukupan energi (BPPP, 2015). Kebutuhan beras di Indonesia setiap tahun meningkat seiring dengan meningkatnya jumlah penduduk, sebaliknya produksi cenderung turun. Sebagai contoh, kebutuhan beras di Riau pada tahun 2014 mencapai 652.875 ton gabah kering giling sedangkan produksi hanya 385.475 ton
(BPS Riau, 2015), berarti terjadi defisit sekitar 3/5 dari kebutuhan. Defisit beras terus meningkat apabila kondisi ini dibiarkan dan akan memperparah kerawanan pangan pada skala nasional.

Budidaya padi gogo pada lahan kering perlu jadi perhatian khusus sebagai alternatif dalam memenuhi kebutuhan beras skala nasional. Ultisol potensinya cukup besar karena luas di Indonesia namun tergolong marjinal untuk budidaya padi gogo. Luasnya sekitar 45.794.000 ha sekitar $25 \%$ dari total luas daratan Indonesia (Prasetyo dan Suriadikarta, 
2006). Kendala-kendala pada Ultisol antara lain reaksi masam, kelarutan dan kejenuhan $\mathrm{Al}$ tinggi sehingga bersifat racun bagi tanaman dan fiksasi $\mathrm{P}$ tinggi, KTK, kandungan $\mathrm{C}$ organik, basa-basa dapat dipertukarkan (K-dd, Ca-dd, Mg-dd dan Na-dd), $\mathrm{P}$ dan $\mathrm{N}$ tersedia rendah (Subagyo et al., 2004). Hal yang sama dilaporkan Yulia et al. (2018) bahwa Ultisol asal Desa Batu Belah, Kampar, Riau bereaksi masam, kandungan $\mathrm{C}$ organik, $\mathrm{N}$ total, $\mathrm{P}$ tersdia, basa-basa (K-dd, Na-dd, dan Mg-dd) dapat ditukar dan KTK rendah, Ca-dd dan KB sangat rendah, sebaliknya kejenuhan Al tinggi.

Pemberian bahan pembenah tanah atau amelioran dan mikroba seperti bakteri fiksasi nitrogen non simbiotik (FNNS) sangat dibutuhkan untuk mengatasi kedala tersebut.. Bahan-bahan seperti biochar dan cocopeat (kelapa) dan kompos tandan kosong kelapa sawit (TKKS) sangat banyak dan mudah diperoleh di Riau dapat dimanfaatkan sebagai amelioran guna meningkatkan produktivitas padi gogo pada Ultisol.

Glaser et al. (2002) melaporkan pemberian biochar berpengaruh positif terhadap sifat tanah seperti stabilitas agregat tanah, KTK tanah, kandungan C-organik tanah, retensi air dan hara. Retensi dan persistensi hara oleh biochar di dalam tanah sangat tinggi dilaporkan (Chan et al., 2007). Endriani (2013) melaporkan biochar cangkang kelapa sawit memiliki $\mathrm{pH}$ 6,71 dan nibah $\mathrm{C} / \mathrm{N} 35,45$, mengandung C-organik 48,56\%, P 0,94\%, K $0,28 \%$, dan dilaporkan bahwa pemberiannya meningkatkan $\mathrm{pH}$ tanah dari 4,36 ke 5,30. Nisa (2010) melaporkan pemberian biochar dosis 10 t ha ${ }^{-1}$ meningkat $\mathrm{pH}$ tanah. Asai et al. (2009) melaporkan pemberian biochar meningkatkan produktivitas padi gogo, dan Gani, (2009) melaporkan bahwa pemberian biochar dosis 4$8 \mathrm{tha}^{-1}$ meningkatkan produktivitas padi sekitar 20-220\%. Selanjutnya Maftuah dan Indrayati (2013) melaporkan pemberian biochar meningkatkan tinggi tanaman, jumlah anakan dan jumlah malai padi dibandingkan tanpa biochar.

Menurut Ghehsareh et al. (2011) kharakteristik cocopeat sebagai berikut: nisbah C/N 48, BD 0,16 g/cm, pH 6,7, KTK 138,7
$\mathrm{Cmol}^{(+)} / \mathrm{kg}$ ), N-total $1,98 \mathrm{mg} / \mathrm{L}, \mathrm{P}$ Olsen 1,32 $\mathrm{mg} / \mathrm{L}$ dan $\mathrm{K}$ olsen $477,7 \mathrm{mg} / \mathrm{L}$.serta porositas $58 \%$ dan water holding capasity (WHC) 90,5\%. Cocopeat mengandung $\mathrm{Ca}, \mathrm{Mg}, \mathrm{K}, \mathrm{Na}$, $\mathrm{N}$ dan $\mathrm{P}$ (Ihsan, 2013). Kandungan air dan daya simpan air pada cocopeat tinggi masingmasing $119 \%$ dan 695,4 \% (Hasriani et al., 2013). Kompos TKKS mengandung hara K, P, $\mathrm{Ca}, \mathrm{Mg}, \mathrm{C}$ dan $\mathrm{N}$, serta berperan memperbaiki sifat fisik, kimia dan biologi tanah (Iwan, 2012). Pemberian kompos TKKS 5 ton ha ${ }^{-1}$ meningkatkan jumlah anakan produktif (Manurung, 2016).

Selain itu Marlina et al. (2013) melaporkan bahwa isolat bakteri Azospirillum sp. dan Azotobacter sp. dapat tumbuh baik pada daerah perakaran dan jaringan tanaman serta mampu memfiksasi $\mathrm{N}_{2}$ di udara yang dikembangkan sebagai pupuk hayati pada tanaman padi. Aquilanti et al. (2004) melaporkan bahwa Azotobacter telah digunakan sebagai inokulum dan efektif meningkatkan pertumbuhan tanaman dan pengendalian hama.

Tujuan penelitian mempelajari pengaruh interaksi pemberian amelioran dan suspensi isolat bakteri FNNS terhadap pertumbuhan dan serapan $\mathrm{N}$ tanaman padi gogo pada medium Ultisol.

\section{BAHAN DAN METODA}

Penelitian dilaksanakan di Rumah Kaca dan Laboratorium Ilmu Tanah Fakultas Pertanian Universitas Riau dari Mei sampai September 2017.

Bahan yang digunakan antara lain bahan tanah Ultisol, benih padi gogo varietas Inpago 8, biochar tempurung kelapa, cocopeat dan kompos TKKS sebagai amelioran, isolat bakteri Azotobacter sp. koleksi Laboratorium Mikrobiologi Fakultas Matematika dan Ilmu Pengetahuan Alam Universitas Riau, Nutrient Agar (NA), Nutrient Browth Powder (NB), aquadest, $\mathrm{NaOH}, \mathrm{H}_{2} \mathrm{SO}_{4}, \mathrm{H}_{2} \mathrm{O}_{2} 50 \%$, selen, $\mathrm{H}_{3} \mathrm{BO}_{3} 1 \%$, indikator $\mathrm{MM}$, polybag ukuran $17,5 \times 40 \mathrm{~cm}$, Urea, SP-36 dan $\mathrm{KCl}$. Alat yang digunakan antara lain: timbangan digital, cawan petri, jarum ose, alumunium foil, batang penyebar, lampu bunsen, wrap plastic, vortex, 
inkubator, blender, alat distruksi dan distilasi dan lain-lain.

Penelitian dilakukan secara eksperimen dalam bentuk faktorial menggunakan rancangan acak lengkap. faktor pertama amelioran terdiri dari 6 macam (biochar, cocopeat, kompos TKKS, biochar + cocopeat, biochar + kompos TKKS masing-masing dosis $50 \mathrm{~g} \mathrm{polybag}^{-1}$ dan tanpa amelioran sebagai kontrol). Faktor Kedua yaitu suspensi isolat bakteri FNNS terdiri dari 3 taraf $(0,10$ dan 20 $\mathrm{ml}$ polybag ${ }^{-1}$ ), tiap kombinasi diulang 3 kali. Parameter yang diamati adalah tinggi tanaman, jumlah anakan, berat kering tajuk dan akar, serapan $\mathrm{N}$ oleh tajuk dan akar tanaman padi gogo. Data hasil pengamatan dianalisis secara statistik menggunakan analisis ragam dan uji lanjut $D N M R T$ pada taraf $5 \%$.

\section{HASIL DAN PEMBAHASAN Tinggi Tanaman}

Tabel 1 menunjukkan bahwa pemberian amelioran biochar, cocopeat dan kompos TKKS secara tunggal atau campuran dosis $50 \mathrm{~g}^{\text {polybag }}{ }^{-1}$ dan suspensi isolat bakteri FNNS dosis 10 dan $20 \mathrm{ml}_{\text {polybag }}{ }^{-1}$ atau tanpa isolat bakteri meningkatkan tinggi tanaman secara nyata dibanding kontrol.

Tabel 1. Pengaruh interaksi amelioran dan suspensi isolat bakteri FNNS terhadap tinggi tanaman padi gogo umur 48 HST pada medium Ultisol

\begin{tabular}{lccc}
\hline \multirow{2}{*}{ Amelioran (g polybag $\left.{ }^{-1}\right)$} & \multicolumn{3}{c}{$\begin{array}{c}\text { Suspensi Isolat Bakteri FNNS } \\
(\mathrm{ml} \text { polybag-1) }\end{array}$} \\
\cline { 2 - 4 } 0 (kontrol) & 6 (kontrol) & 10 & 20 \\
50 Biochar & $83,17 \mathrm{~d}$ & $71,97 \mathrm{~cd}$ & $79,13 \mathrm{bc}$ \\
50 Cocopeat & $84,77 \mathrm{ab}$ & $88,00 \mathrm{ab}$ & $88,47 \mathrm{a}$ \\
50 Kompos TKKS & $86,43 \mathrm{ab}$ & $87,20 \mathrm{ab}$ & $86,90 \mathrm{ab}$ \\
Campuran (25 Biochar+25 Cocopeat) & $86,67 \mathrm{ab}$ & $88,27 \mathrm{a}$ & $87,87 \mathrm{ab}$ \\
Campuran (25 Biochar+25 Kompos TKKS) & $81,27 \mathrm{ab}$ & $86,57 \mathrm{ab}$ & $86,67 \mathrm{ab}$ \\
\hline
\end{tabular}

Ket : Angka pada baris dan kolom yang diikuti oleh huruf kecil yang sama menunjukkan berbeda tidak nyata menurut uji DNMRT pada taraf $5 \%$.

Hal ini menunjukkan bahwa biochar, cocopeat dan kompos TKKS sebagai amelioran berperan dalam memperbaiki kimia, sifat fisik dan biologi tanah meskipun memiliki karakter yang berbeda, sedangkan isolat bakteri FNNS meningkatkan ketersdiaan $\mathrm{N}$ melalui fiksasi $\mathrm{N}_{2}$ udara. Kompos TKKS berperan memperbaiki sifat fisik, kimia dan biologi tanah (Iwan, 2012).
Perbaikan sifat kimia tanah erat kaitannya dengan karakteristiknya yaitu mengandung hara esensial. Biochar cangkang kelapa sawit mengandung C-organik 48,56\%, P $0,94 \%$ dan $\mathrm{K} 0,28 \%$, serta meningkatkan $\mathrm{pH}$ tanah (Endriani, 2013). Cocopeat mengandung hara esensial seperti $\mathrm{K}, \mathrm{P}, \mathrm{Ca}$, dan $\mathrm{Mg}$ (Ghehsareh et al., 2011; Ihsan, 2013), kompos TKKS mengandung hara $\mathrm{N}, \mathrm{P}, \mathrm{K}, \mathrm{Ca}$ dan $\mathrm{Mg}$ (Iwan, 2012). Pemberian biochar berpengaruh 
positif terhadap sifat tanah seperti KTK tanah, kandungan C-organik tanah dan retensi hara (Glaser et al., 2002). Perbaikan sifat fisik tanah erat kaitannya kharakteristik biochar, cocopeat dan kompos TKKS yaitu memiliki porositas sangat tinggi, BV rendah dan kemampuan menjerap dan memegang air sangat tinggi (Glaser et al., 2002; Ghehsareh et al., 2011; Iwan, 2012). Cocopeat memiliki kandungan air dan daya simpan air tinggi masing-masing 119 $\%$ dan 695,4 \% (Hasriani et al., 2013). Pemberian biochar berpengaruh positif terhadap sifat tanah seperti stabilitas agregat tanah dan retensi air (Glaser et al., 2002). Perbaikan biologi tanah erat kaitannya dengan peranannya sebagai sumber carbon dan energi bagi mikroorganisme karena selulosa dan hemiselulosanya tinggi. Cocopeat sebagai sumber karbon dan energi serta tempat berkembang biak bagi mikroorganisme (Istomo dan Valentino, 2012). Amelioran tersebut menekan fiksasi $\mathrm{P}$ di tanah dan meningkatkan ketersediaannya. Wuryesiliane (2013) juga melaporkan bahwa pemberian Azotobacter sp. meningkatkan tinggi tanaman padi dibanding kontrol.

Kondisi dimana sifat fisik tanah baik memudahkan akar tumbuh dan berkembang sehingga volume akar meningkatkan cepat (Tabel 4) Peningkatan volume akar diikuti peningkatan ketersediaan air dan hara menyebabkan serapan air dan hara oleh tanaman juga meningkat. Selanjutnya memacu proses fisiologi dan metabolisme tanaman dalam menghasilkan berbagai senyawa organik. Diantara senyawa organik yang dihasilkan adalah protein, selulosa, hemiselulosa dan lignin sebagai komponen penyusun inti sel dan jaringan tanaman, sehingga terjadi peningkatan pertumbuhan atau penambahan tinggi tanaman.

\section{Jumlah Anakan}

Pemberian amelioran biochar cocopeat dan kompos TKKS secara tunggal atau campuran dosis $50 \mathrm{~g}$ polybag ${ }^{-1}$ meningkatkan jumlah anakan secara nyata dibanding kontrol, peningkatannya semakin besar bila diikuti dengan pemberian suspensi isolat bakteri FNNS dosis 10 dan $20 \mathrm{ml}$ polybag $^{-1}$ yaitu meningkat hampir 2 kali dibandingkan kontrol (Tabel 2). Seperti telah dijelaskan bahwa bahwa peningkatan senyawa organik hasil proses fotosintesis dan proses metabolisme akibat meningkatnya serapan hara dan air karena tersedia meningkat dengan pembelian amelioran dan suspensi isolat bakteri FNNS. Produk metabolisme berupa asam amino atau protein akan semakin tinggi terbentuk dengan semakin banyaknya $\mathrm{N}$ diserap tanaman (Tabel 5).

Tabel 2. Pengaruh interaksi amelioran dan suspensi isolat bakteri FNNS terhadap jumlah anakan padi gogo umur 48 HST pada medium Ultisol

\begin{tabular}{llll}
\hline \multirow{2}{*}{ Amelioran (g polybag $\left.{ }^{-1}\right)$} & \multicolumn{3}{c}{$\begin{array}{c}\text { Suspensi Isolat Bakteri FNNS } \\
\left(\mathrm{ml} \text { polybag }{ }^{-1}\right)\end{array}$} \\
\cline { 2 - 4 } & 0 (kontrol) & 10 & 20 \\
\hline 0 (kontrol) & $6,67 \mathrm{f}$ & $7,00 \mathrm{ef}$ & $9,00 \mathrm{def}$ \\
50 Biochar & $10,67 \mathrm{abcde}$ & $13,00 \mathrm{ab}$ & $12,00 \mathrm{abc}$ \\
50 Cocopeat & $9,00 \mathrm{cdef}$ & $10,00 \mathrm{abcdef}$ & $10,67 \mathrm{abcde}$ \\
50 Kompos TKKS & $9,67 \mathrm{bcdef}$ & $13,33 \mathrm{ab}$ & $13,67 \mathrm{a}$ \\
Campuran $(25$ Biochar+25 Cocopeat) & $10,33 \mathrm{abcdef}$ & $11,00 \mathrm{abcd}$ & $12,00 \mathrm{abc}$ \\
Campuran (25 Biochar+25Kompos TKKS) & $12,67 \mathrm{abc}$ & $13,00 \mathrm{ab}$ & $13,00 \mathrm{ab}$ \\
\hline
\end{tabular}

Ket : Angka pada baris dan kolom yang diikuti oleh huruf kecil yang sama menunjukkan berbeda tidak nyata menurut uji DNMRT pada taraf $5 \%$.

Gardner et al. (1991) menyatakan
bahwa pertumbuhan anakan tanaman maksimum didukung oleh sifat genetik tanaman dan kondisi lingkungan yang sesuai 
diantaranya ketersediaan unsur hara. Ketiga jenis amelioran ikut berperan meningkatkan ketersediaan hara dan air bagi tanaman. Nitrogen udara yang difiksasi bakteri FNNS diinkorporasi menjadi senyawa penyusun sel bakteri, selanjutnya akan tersedia untuk tanaman setelah bakteri mati dan terdekomposisi. Peningkatan ketersediaan hara terutama $\mathrm{N}$ di dalam tanah menyebabkan serapan $\mathrm{N}$ meningkat oleh tanaman. Dalam tanaman $\mathrm{N}$ berperan sebagai komponen penyusun klorofil dan asam amino. Selanjutnya asam-amino berguna dalam pembentukan protein. Proses fotosintesis terjadi bila ada klorofil, dengan demikian semakin tinggi serapan $\mathrm{N}$ semakin banyak klorofil terbentuk sehingga semakin besar dihasilkan karbohidrat/fotosintat. Unsur $\mathrm{N}$ dan $\mathrm{C}, \mathrm{H}, \mathrm{O}$ dalam bentuk karbohidrat/fotosintat dengan adanya $\mathrm{S}$ atau tidak dikonversi menjadi senyawa asam amino atau protein melalui proses metabolisme (Jones, et al., 1991). Selanjutnya protein di dalam tanaman berperan sebagai komponen penyusun inti sel dan sebagai enzim. Pertumbuhan/pertambahan jaringan tanaman diawali oleh pembelahan inti sel. Enzim berperan dalam proses metabolisme karena reaksinya adalah enzimatik artinya kehadiran enzim akan memacu proses metabolisme Oleh sebab itu semakin tinggi ketersediaan $\mathrm{N}$ semakin terpacu proses metabolisme dan semakin banyak senyawa organik sebagai komponen penyusun sel terbentuk. Menurut Lakitan (2004), nitrogen berperan dalam pembentuk klorofil dan protein, peningkatannya berbanding lurus dengan fotosintat yang dihasilkan. Manurung (2016) melaporkan bahwa pemberian kompos TKKS 5 ton ha ${ }^{-1}$ meningkatkan jumlah anakan produktif dibandingkan tanpa kompos. Selanjutnya Maftuah dan Indrayati (2013) melaporkan pemberian biochar meningkatkan jumlah anakan dan jumlah malai padi dibandingkan tanpa biochar. Syam'un dan Dachlan (2007) juga melaporkan bahwa pemberian isolat bakteri Azotobacter sp meningkatkan jumlah anakan dibandingkan tanpa pemberian isolat.

\section{Berat Kering Tajuk}

Berat kering tajuk padi gogo meningkat nyata pada semua jenis amelioran dosis $50 \mathrm{~g}$ polybag ${ }^{-1}$ tanpa atau diikuti pemberian suspensi isolat bakteri FNNS dosis 10 dan $20 \mathrm{ml}$ polybag $^{-1}$ dibanding kontrol (Tabel 3). Berat kering tajuk meningkat lebih tinggi pada pemberian biochar, kompos TKKS dan campuran biochar dengan kompos TKKS diikuti pemberian suspensi isolat bakteri FNNS dosis 10 dan $20 \mathrm{ml}$ polybag $^{-1}$ dibandingkan kombinasi lain, peningkatannya hampir 3 kali kantrol.

Tabel 3. Pengaruh interaksi amelioran dan suspensi isolat bakteri FNNS terhadap berat kering tajuk padi gogo umur 48 HST pada medium Ultisol

\begin{tabular}{|c|c|c|c|}
\hline \multirow[t]{2}{*}{ Amelioran (g polybag $\left.{ }^{-1}\right)$} & \multicolumn{3}{|c|}{$\begin{array}{l}\text { Suspensi Isolat Bakteri FNNS } \\
\left(\mathrm{ml} \text { polybag }{ }^{-1}\right)\end{array}$} \\
\hline & 0 (kontrol) & 10 & 20 \\
\hline 0 (kontrol) & $3,60 \mathrm{e}$ & $4,08 \mathrm{e}$ & $4,53 \mathrm{e}$ \\
\hline 50 Biochar & 8,64 abcd & $9,79 \mathrm{abc}$ & $10,07 \mathrm{abc}$ \\
\hline 50 Cocopeat & $6,99 \mathrm{~d}$ & $7,43 \mathrm{~cd}$ & $7,34 \mathrm{~cd}$ \\
\hline 50 Kompos TKKS & 9,05 abcd & $10,50 \mathrm{a}$ & $10,72 \mathrm{a}$ \\
\hline Campuran (25 Biochar +25 Cocopeat $)$ & $7,38 \mathrm{~cd}$ & $7,57 \mathrm{bcd}$ & $7,44 \mathrm{~cd}$ \\
\hline Campuran (25 Biochar + 25 Kompos TKKS) & $9,62 \mathrm{abcd}$ & $10,29 \mathrm{ab}$ & $10,05 \mathrm{abc}$ \\
\hline
\end{tabular}

Ket : Angka pada baris dan kolom yang diikuti oleh huruf kecil yang sama menunjukkan berbeda tidak nyata menurut uji DNMRT pada taraf $5 \%$. 
Hal ini erat kaitannya dengan ketersediaan hara. Pada pemberian biochar dan kompos TKKS hara lebih tersedia daripada cocopeat, karena keduanya telah mengalami penguraian baik melalui pirolisis maupun dekomposisi, sedangkan cocopeat sulit terdekomposisi. Pemberian cocopeat mendorong pertumbuhan dan perkembangan mikroorganisme karena ketersediaan C-organik dan energinya lebih tinggi daripada biochar dan kompos TKKS sehingga meningkatkan jumlah populasi mikroorganisme. Akibat terjadi persaingan antara tanaman padi dan mikroorganisme dalam menyerap hara tersedia. Cocopeat sebagai sumber karbon dan energi serta tempat berkembang biak mikroorganisme (Istomo dan Valentino, 2012). Selulosa dan hemiselulosa biochar habis habis karena proses pirolisis dan pada kompos TKKS habis karena manfaatkan mikroorganisme. Lakitan (2004) menyatakan bahwa tinggi rendahnya berat kering tanaman tergantung ketersediaan hara dan serapan hara oleh akar tanaman selama proses pertumbuhan. Siregar et al. (2015) melaporkan berat kering tajuk cenderung meningkatkan dengan pmberian kompos TKKS $5 \mathrm{t} \mathrm{ha}^{-1}$ dibandingkan tanpa kompos.

\section{Berat Kering Akar}

Tabel 4 menunjukkan bahwa berat kering akar meningkat nyata pada pemberian cocopeat dosis $50 \mathrm{~g}$ polybag diikuti pemberian suspensi isolat bakteri FNNS dosis 10 dan kompos TKKS dosis $50 \mathrm{~g}_{\text {polybag }}{ }^{-1}$ diikuti pemberian suspensi isolat bakteri FNNS dosis 10 dan $20 \mathrm{ml}$ polybag-1, sedangkan pada kombinasi lain tidak nyata dibandingkan kontrol.

Hal ini erat kaitannya dengan peran amelioran dalam memperbaiki lingkungan perakaran. Pemberian cocopeat dan kompos TKKS berperan terhadap perbaikan sifat fisik tanah terutama porositas tanah meningkat lebih besar dibandingkan pemberian biochar.

Tabel 4. Pengaruh interaksi amelioran dan suspensi isolat bakteri FNNS terhadap berat kering akar padi gogo umur 48 HST pada medium Ultisol

\begin{tabular}{|c|c|c|c|}
\hline \multirow{2}{*}{ Amelioran (g polybag ${ }^{-1}$ ) } & \multicolumn{3}{|c|}{$\begin{array}{l}\text { Suspensi Isolat Bakteri FNNS } \\
\left(\mathrm{ml} \text { polybag } \mathrm{g}^{-1}\right)\end{array}$} \\
\hline & 0 (kontrol) & 10 & 20 \\
\hline 0 (kontrol) & $1,86 \mathrm{~d}$ & $2,40 \mathrm{~d}$ & $3,06 \mathrm{~d}$ \\
\hline 50 Biochar & $3,75 \mathrm{bcd}$ & 4,68 abcd & $4,93 \mathrm{abcd}$ \\
\hline 50 Cocopeat & $3,80 \mathrm{bcd}$ & $4,87 \mathrm{abcd}$ & $7,24 \mathrm{ab}$ \\
\hline 50 Kompos TKKS & $3,17 \mathrm{~d}$ & $7,63 \mathrm{a}$ & $6,91 \mathrm{abc}$ \\
\hline Campuran (25 Biochar +25 Cocopeat $)$ & $3,51 \mathrm{~cd}$ & $4,34 \mathrm{abcd}$ & 4,19 abcd \\
\hline Campuran (25 Biochar + 25 Kompos TKKS) & $4,13 \mathrm{abcd}$ & $4,85 \mathrm{abcd}$ & $6,78 \mathrm{abc}$ \\
\hline
\end{tabular}

Ket : Angka pada baris dan kolom yang diikuti oleh huruf kecil yang sama menunjukkan berbeda tidak nyata menurut uji DNMRT pada taraf $5 \%$.

Pemberian cocopeat dan kompos TKKS menyebabkan tanah lebih gembur sehingga lebih mudah ditembus akar dan difusi oksigen besar ke daerah sehingga lebih memacu proses respirasi akar. Bila respirasi akar lebih baik maka energi yang dihasilkan lebih tinggi. Energi hasil respirasi akar berguna dalam penyerapan hara secara aktif dan pembelahan sel akar sehingga akar tumbuh dan berkembang lebih pesat. Volume akar meningkat tercermin pada tingginya berat kering akar.

\section{Serapan N Tajuk}

Serapan $\mathrm{N}$ tajuk meningkat dengan pemberian amelioran biochar, cocopeat dan kompos TKKS secara tunggal atau campuran dosis $50 \mathrm{~g}$ polybag $^{-1}$ tanpa isolat bakteri FNNS, 
peningkatannya lebih besar bila diikuti pemberian suspensi iosolat bakteri FNNS dosis 10 dan $20 \mathrm{ml} \mathrm{polybag}^{-1}$ dibandingkan kontrol (Tabel 5). Hal ini menunjukkan bahwa pemberian amelioran berperan dalam meningkatkan serapan $\mathrm{N}$ melalui perbaikan sifat komia, fisika dan biologi tanah. Peran amelioran dalam perbaikan sifat kimia karena berkontribusi menyediakan $\mathrm{N}$, sifat fisik karena berperan dalam pembentukan dan kemantapan agregat sehingga porositas tanah meningkat akibatnya difusi gas $\mathrm{N} 2$ undara meningkat ke rizosfer, terdap sifat biologi karena kemampuan menjerap dan menahan air tinggi sehingga menyediakan air, karbon dan energi bagi mikroorganisme.

Tabel 5. Pengaruh interaksi amelioran dan suspensi isolat bakteri FNNS terhadap serapan $\mathrm{N}$ tajuk padi gogo umur 48 HST pada medium Ultisol

\begin{tabular}{|c|c|c|c|}
\hline \multirow[t]{2}{*}{ Amelioran (g polybag ${ }^{-1}$ ) } & \multicolumn{3}{|c|}{$\begin{array}{c}\text { Suspensi Isolat Bakteri FNNS } \\
\left(\mathrm{ml} \text { polybag }^{-1}\right)\end{array}$} \\
\hline & 0 (kontrol) & 10 & 20 \\
\hline 0 (kontrol) & $2,62 \mathrm{f}$ & $4,21 \mathrm{f}$ & $4,65 \mathrm{f}$ \\
\hline 50 Biochar & 19,61 abcde & $21,18 \mathrm{abcd}$ & 23,07 abcd \\
\hline 50 Cocopeat & $15,79 \mathrm{de}$ & 16,16 cde & 16,79 bcde \\
\hline 50 Kompos TKKS & $23,78 \mathrm{abcd}$ & 24,60 abcd & $26,97 \mathrm{abcd}$ \\
\hline Campuran (25 Biochar +25 Cocopeat $)$ & 10,20 ef & 13,38 bcde & $23,40 \mathrm{abcd}$ \\
\hline Campuran (25 Biochar+25 Kompos TKKS) & $27,39 \mathrm{abc}$ & $27,65 \mathrm{ab}$ & $29,75 \mathrm{a}$ \\
\hline
\end{tabular}

Ket : Angka pada baris dan kolom yang diikuti oleh huruf kecil yang sama menunjukkan berbeda tidak nyata menurut uji DNMRT pada taraf $5 \%$.

Kondisi tersebut mendukung untuk pertumbuhan dan perkembangan isolat bakteri FNNS, dengan demikian perannya meningkat menyediakan untuk tanaman. Pada kondisi N tersedia tinggi maka yang diserap tanaman juga tinggi selanjunya memacu proses fisiologi dan metabolisme dalam tanaman akhirnya mendorong pertumbuhan tajuk tanaman. Peningkatan serapan $\mathrm{N}$ meningkatkan kandungan $\mathrm{N}$ tanaman diikuti peningkatan berat kering tajuk (Tabel 3) menyebabkan serapan $\mathrm{N}$ oleh tajuk meningkat. Berat kering tanaman menunjukkan status hara dalam tanah dan jumlah hara yang diserap oleh tanaman serta laju fotosintesis (Dwidjoseputro, 1983). Pemberian biochar meningkatkan kandungan N tanaman dibandingkan tanpa biochar (Utomo dan Islami, 2016). Wuriesyliane et al. (2013) melaporkan bahwa serapan $\mathrm{N}$ tanaman padi terbaik diperoleh pada perlakuan Azospirillum sp. dan bakteri endofitik. Berat kering tajuk menunjukkan status nutrisi suatu tanaman dan sangat erat kaitannya dengan ketersediaan hara dan serapan hara (Prawiratna et al., 1995).

\section{Serapan N Akar}

Serapan N oleh akar menunjukkan pola hampir sama dengan serapan $\mathrm{N}$ tajuk, dimana serapan $\mathrm{N}$ oleh akar pada pemberian amelioran biochar, cocopeat dan kompos TKKS dosis $50 \mathrm{~g}$ polybag ${ }^{-1}$ diikuti pemberian suspensi isolat bakteri FNNS dosis 10 dan $20 \mathrm{ml}$ polybag $^{-1}$ lebih tinggi daripada tanpa pemberian isolat bakteri dan meningkat secara nyata dibandingkan kontrol. Hal ini erat kaitannya dengan berat kering akar (Tabel 4) yang juga lebih tinggi pada pemberian amelioran biochar, cocopeat dan kompos TKKS dosis $50 \mathrm{~g}_{\text {polybag }}{ }^{-1}$ diikuti pemberian isolat bakteri FNNS dosis 10 dan $20 \mathrm{ml}$ polybag $^{-1}$ dari pada tanpa pemberian isolat bakteri.

Hal ini menunjukkan bahwa pemberian suspensi isolat bakteri FNNS memberikan pengaruh lebih baik terhadap ketersediaan $\mathrm{N}$ dan serapan $\mathrm{N}$ oleh akar dan didukung oleh pemberian ke tiga jenis amelioran tersebut. Hal yang sama dilaporkan Syam'un dan Dachlan 
(2007), melaporkan bahwa pemberian pupuk hayati mengandung bakteri Azospirillum sp, meningkatkan serapan hara tanaman padi. Guntoro (2003), menyatakan bahwa inokulasi CMA dan Azospirillum sp. dapat meningkatkan kandungan N dan serapan N. Manurung (2016) melaporkan bahwa pemberian kompos TKKS 5 $\mathrm{t}$ ha $^{-1}$ meningkatkan laju pertumbuhan relatif dan serapan hara tanaman. Siregar (2015) melaporkan bahwa serapan hara $\mathrm{N}$ tanaman padi cenderung meningkat dengan meningkatnya dosis abu boiler ke $750 \mathrm{~kg}$ $\mathrm{ha}^{-1}$ dicampur kompos TKKS 5 ton $\mathrm{ha}^{-1}$ dibandingkan tanpa kompos TKKS.

Tabel 6. Pengaruh interaksi amelioran dengan suspensi isolat bakteri FNNS terhadap serapan N oleh akar padi gogo umur 48 HST pada medium Ultisol

\begin{tabular}{|c|c|c|c|}
\hline \multirow[t]{2}{*}{ Amelioran (g polybag ${ }^{-1}$ ) } & \multicolumn{3}{|c|}{$\begin{array}{c}\text { Suspensi Isolat Bakteri FNNS } \\
\left(\mathrm{ml} \text { polybag }{ }^{-1}\right)\end{array}$} \\
\hline & 0 (kontrol) & 10 & 20 \\
\hline 0 (kontrol) & $1,52 \mathrm{f}$ & 2,40 ef & 3,59 def \\
\hline 50 Biochar & 6,04 cdef & 8,19 abcd & $8,46 \mathrm{abcc}$ \\
\hline 50 Cocopeat & $6,47 \mathrm{cdef}$ & 8,36 abcd & $12,87 \mathrm{ab}$ \\
\hline 50 Kompos TKKS & $4,28 \mathrm{def}$ & 13,42 a & $10,64 \mathrm{abc}$ \\
\hline Campuran (25 Biochar + 25 Cocopeat $)$ & 6,43 cdef & 5,08 cdef & 7,11 cdef \\
\hline Campuran (25 Biochar + 25 Kompos TKKS) & 6,28 cdef & 7,80 bcde & $8,61 \mathrm{abcc}$ \\
\hline
\end{tabular}

Ket : angka pada baris dan kolom yang diikuti oleh huruf kecil yang sama menunjukkan berbeda tidak nyata menurut uji DNMRT pada taraf $5 \%$.

\section{KESIMPULAN}

Pemberian amelioran biochar, cocopeat dan kompos TKKS secara tunggal atau campuran dosis $50 \mathrm{~g}$ tanpa diikuti atau diikuti pemberian suspensi isobat bakteri FNNS dosis 10 dan $20 \mathrm{ml}$ polybag $^{-1}$ meningkatkan tinggi tanaman, jumlah anakan, berat kering tajuk dan serapan $\mathrm{N}$ oleh tajuk secara nyata dibandingkan kontrol.

\section{DAFTAR PUSTAKA}

Aquilanti, L., F. Favilli, F. Clementi. 2004. Comparison of different strategies for isolation and preliminary identification of Azotobacter from soil samples. Soil Biol. Biochem. 36: 1475-1483.

Asai, H., B. K. Samson, Haefele, M. Stephan, K Songyikhangsuthor, K. Homma, Y. Kiyono, Y. Inoue, T. Shiraiwa dan T. Horie. 2009. Biochar amendment techniques for upland rice production in Northern Laos : 1 : Soil physical properties, leaf
SPAD and grain yield. Field Crops, volume 111 (1-2) : 81-84.

Badan Penelitian dan Pengembangan Pertanian (BPPP). 2015. Petunjuk Pelaksanaan Percobaan Uji Multilokasi Padi Padi Gogo. Malang.

Badan Pusat Statistik (BPS) Riau. 2015. Riau dalam Angka. BPS. Pekanbaru.

Chan, K.Y., van Zwieten, B.L., Meszaros, I., Downie, D. \& Joseph, S., 2007. Agronomic values of greenwaste biochars as a soil amandments. Australian Journal of Soil Research,45,625-634.

Endriani., Sunarti, dan Ajidirman. (2013). Pemanfaatan Biochar Cangkang Kelapa Sawit sebagai Soil Amandement Ultisol Sungai BaharJambi. Jurnal Penelitian Universitas Jambi seri sains. Volume 15 (1) : 3946. 
Gani, A., 2009. Biochar Penyelamat Lingkungan. Balai Besar Penelitian Tanaman Padi, Warta Penelitian dan Pengembangan Pertanian, Vol 31 No.6 2009.

Glaser. 2002. Ameliorating Physical and Chemical Properties of Highly Weathered Soils in The Tropics With Charcoal: A review, Biol. Fertil. Soils. (35): 219-230.

Gani, A. 2009. Potensi arang hayati biochar sebagai komponen teknologi perbaikan produktivitas lahan pertanian. Jurnal Iptek Tanaman Pangan, volume 4 (1): 33-48.

Gardner, F. P, R. B. Pearce dan R. L Mitchell. 1991. Fisiologi Tanaman Budidaya. Universitas Indonesia Press. Jakarta.

Ghehsareh, A. M, H. Borji and M. Jafarpour. 2011. Effect of some culture substrates (date-palm peat, cocopeat and perlite on some growing indices and nutrient elements uptake in greenhouse tomato. African Journal of Microbiology Research Vol. 5(12), pp. 1437-1442.

Guntoro, D. 2003. Pemanfaatan cendawan mikoriza arbuskula dan bakteri Azospirillum untuk meningkatkan efisiensi pemupukan pada Turfgrass. Thesis Institut Pertanian Bogor (Tidak dipublikasikan).

Hasriani, D. Kusnadi, dan A. Saputra. 2013. Kajian Serbuk Sabut Kelapa (Cocopeat) Sebagai Media Tanam. Departemen Teknik Sipil dan Lingkungan. Fakultas Teknologi Pertanian. IPB. Bogor.

Ihsan, M. 2013. Manfaat Serbuk Cocopeat / Serbuk Sabut Kelapa. Penebar Swadaya. Jakarta.
Istomo dan Valentino. 2012. Pengaruh perlakuan kombinasi media terhadap pertumbuhan anakan tumih (Combretocarpus rotundatus (Miq.) Danser). Jurnal Silvikultur Tropika, volume 3 (2): 81-84.

Iwan, R. 2012. Tandan Kosong Kelapa Sawit (TKKS) sebagai Alternatif Pupuk Organik. Erlangga. Jakarta.

Jones, J.B., B. Wolf and H. A. Mills. 1991. Plant analysis handbook: a ractical sample, preparation, analysis, and interpretation.

Lakitan, B. 2004. Dasar - Dasar Fisiologi Tumbuhan. Raja Gravindo Persada. Jakarta.

Maftu'ah, E. and L. Indrayati. 2013. The use of biochar to improve soil properties and growth of paddy in peatland. Agrivita volume 35 (3). Pp 290-295.

Manurung, B., J. Sjofjan dan Armaini. 2016. Aplikasi abu sekam padi dan kompos tkks pada padi gogo (Oryza sativa L.) di areal gawangan kelapa sawit pada lahan gambut. JOM Faperta, volume 3 (1): $1-15$.

Marlina, N., Silviana dan N. Gofar. 2013. Seleksi bakteri penambat nitrogen (Azospirillum dan Azotobacter) asal rhizosfer tanaman budidaya di lahan lebak untuk memacu pertumbuhan tanaman padi. Disampaikan pada Prosiding Seminar Nasional dan Rapat Tahunan Bidang Ilmu-ilmu Pertanian BKS-PTN Wilayah Barat. Pontianak.

Nisa, K. 2010. Pengaruh pemupukan npk dan biochar terhadap sifat kimia tanah, serapan hara dan hasil tanaman padi sawah. Thesis Universitas Syiah Kuala. Banda Aceh. (Tidak dipublikasikan). 
Norsalis, E. 2011. Padi Gogo dan Padi Sawah. Repositori Universitas Sumatera Utara. Medan.

Prasetyo, B.H. dan D.A. Suriadikarta. 2006. Karakteristik, potensi dan teknologi pengelolaan tanah ultisol untuk pengembangan pertanian lahan kering di Indonesia. Jurnal Litbang Pertanian, volume 25 (2): 39-46.

Prawiranata W. S. Harran dan P Tjondronegoro. 1988. Dasar-Dasar Fisiologi Tumbuhan. Departemen Botani Fakultas Pertanian IPB. Bogor.

Siregar, M. D. W., Nelvia dan H. Yetti. 2015. Aplikasi pupuk nitrogen dan campuran kompos tandan kosong kelapa sawit dengan abu boiler terhadap serapan hara npk oleh tanaman padi (Oryza sativa L.). JOM Faperta, volume 2 (1) : $1-11$.

Subagyo, H., N. Suharta, dan A. B. Siswanto. 2004. Tanah - tanah Pertanian di Indonesia. Pusat Penelitian dan Pengembangan Tanah dan Agroklimat, Bogor.
Syam'un, E. dan A. Dachlan. 2007. Pengembangan Agen Mikroba Penambat Nitrogen Non Simbiotik untuk Aplikasi Tanaman Padi. Lembaga Penelitian dan Pengabdian Masyarakat Universitas Hasanuddin. Makassar.

Utomo, W. H. dan T. Islami 2016. Nitrogen fertilizer requirement of maize (Zea mays L.) on biochar-treated soil. Telah disampaikan pada Prosiding Biochar for future food security. Bogor.

Wuriesyliane, N. Gofar, A. Madjid, H. Widjajanti dan N. L. Putu.2013. Pertumbuhan dan hasil padi pada inseptisol asal rawa lebak yang diinokulasi berbagai konsorsium bakteri penyumbang unsur hara. Jurnal Lahan Suboptimal, volume 2 (1): 1827.

Yulia, R, N. Nelvia, E. Ariani. 2018. Pengaruh campuran cocopeat dan rock phosphate terhadap pertumbuhan dan hasil tiga varietas padi gogo (oryza sativa 1.) pada medium ultisol. J. Solum Vol. XV (1), Januari 2018: 17-25 